\title{
KAJIAN UNSUR BUDAYA JAWA DAN NILAI SOSIAL NOVEL GADIS PANTAI KARYA PRAMOEDYA ANANTA TOER SEBAGAI MATERI PEMBELAJARAN SASTRA DI SMA
}

\author{
Ratna Nisrina Puspitasari, Suyitno, Slamet Mulyono \\ Universitas Sebelas Maret \\ Email: ratnanisrina@gmail.com
}

\begin{abstract}
Abstrak: Penelitian ini bertujuan untuk mendeskripsikan: (1) latar belakang pengarang novel Gadis Pantai,; (2) pengungkapan unsur-unsur budaya Jawa, (3) nilai sosial dalam novel Gadis Pantai; dan (4) relevansi novel Gadis Pantai sebagai materi pembelajaran sastra di SMA. Penelitian ini menggunakan metode kualitatif deskriptif. Sumber data yang digunakan berupa dokumen dan informan. Teknik pengambilan sampel menggunakan purposive sampling. Teknik pengumpulan data menggunakan teknik analisis dokumen dan wawancara. Validitas data dilakukan dengan triangulasi teori dan triangulasi sumber. Analisis data menggunakan analisis interaktif. Hasil penelitian menunjukkan: (1) latar belakang pengarang novel Gadis Pantai yang berkaitan erat dengan latar beakang keluarga dan sosial; (2) pengungkapan unsur-unsur budaya Jawa; (3) nilai sosial yang meliputi nilai ketekunan/kerja keras, nilai kejujuran, nilai tolong menolong, nilai kesopanan, nilai individu; (4) novel Gadis Pantai dapat dijadikan sebagai materi pembelajaran sastra di SMA pada kelas X, XI, dan XII, khususnya pada pembelajaran pada KD 3.7 dan 4.7 di kelas XI peminatan serta KD 3.8 dan KD 4.8 di kelas XII wajib.
\end{abstract}

Kata kunci : budaya Jawa, nilai sosial, novel Gadis Pantai, materi pembelajaran sastra

\section{JAVANESE CULTURE AND SOCIAL VALUE STUDY OF “GADIS PANTAI” NOVEL BY PRAMOEDYA ANANTA TOER AS LITERATURE LEARNING MATERIAL IN SENIOR HIGH SCHOOL}

\begin{abstract}
The research aims to describe (1) the author's background of the Gadis Pantai nove, (2) disclosure of elements of Javanese culture; (3) social values in the Gadis Pantai novel; and (4) the relevance of Gadis Pantai novel as literature learning material in senior high school. This research uses qualitative descriptive method. The data source used is in the form of documents and informants. The sampling technique uses purposive sampling. Data collection techniques use document analysis and interview techniques. The validity of the data is done by theoretical triangulation and source triangulation. Data analysis using interactive analysis. The results of the study show: (1) the author's background of the Gadis Pantai novel that is closely related to family and social background; (2) the disclosure of elements of Javanese culture; (3) social values which include the value of perseverance / hard work, honesty values, values of helpful help, politeness values, individual values; (5) Gadis Pantai novel can be used as literary learning material in senior high schools for class X, XI, and XII, especially in learning in KD 3.7 and 4.7 in special class XI and KD 3.8 and KD 4.8 in class XII required.
\end{abstract}

Keywords: Javanese culture, social values, Gadis Pantai novel, literature learning material.

\section{PENDAHULUAN}

Sastra merupakan salah satu materi yang diajarkan dalam lingkup mata pelajaran bahasa Indonesia dalam kurikulum yang berlaku, khususnya pada jenjang SMA. Salah satu objek kajian sastra yang dikaji dalam kurikulum SMA adalah kajian tentang novel. Novel merupakan jagad realita yang di dalamnya terjadi peristiwa dan perilaku yang dialami dan diperbuat manusia (tokoh) (Minderop, 2011: 78).

Karya sastra dalam hal ini novel diciptakan untuk dijadikan bahan dan

BASASTRA Jurnal Bahasa, Sastra, dan Pengajarannya

Volume 8 Nomor 1, April 2020, P-ISSN 2302-6405, E-ISSN 2714-9765 
sumber pengajaran bagi pembaca. Unsurunsur di dalamnya bersifat sosial, yang berarti sastra menampilkan gambaran kehidupan, dan kehidupan itu merupakan suatu kenyataan sosial (Damono, 2002). Selain itu, karya sastra merupakan cerminan budaya masyarakat yang tercipta melalui proses sosial. Walaupun demikian, pada dasarnya karya sastra tidak terlepas dari unsur-unsur yang bersifat fiktif karena fiksi adalah ciri khas teks sastra dan karena itulah dapat membentuk penelitian alami untuk penelitian sastra (Ronen, 1994).

Nilai budaya dan sosial yang terkandung dalam karya sastra, khusunya novel dapat dijadikan sebagai materi pembelajaran sastra untuk jenjang SMA. Sesuai dengan yang disebutkan di atas, kajian novel selaras dengan kurikulum SMA melalui kompetensi dasar yang harus dipenuhi dalam pembelajaran. Dalam kurikulum, materi pembelajaran merupakan komponen penting yang tidak dapat diabaikan dalam pembelajaran. Materi pembelajaran merupakan salah satu komponen penting dalam kegiatan pembelajaran dan pemilihannya perlu dipertimbangkan dengan baik.

Kehidupan manusia dalam novel merupakan ungkapan, ide, dan imajinasi yang dituangkan oleh novel. Novel mencerminkan budaya adiluhung yang ingin dituangkan pengarang ke dalam tulisannya agar dapat menjadi pengajaran bagi pembacanya. Namun seiring dengan perkembangan zaman dan transfer budaya, novel bukan lagi membahas ataupun menceritakan budaya adilihung yang berisi pengajaran tentang nilai-nilai luhur yang ingin disampaikan pengarang. Novel di era sekarang atau sering disebut oleh kalangan sastrawan sebagai novel populer, tidak jarang hanya berisi dan membahas romansa percintaan antar manusia yang kurang akan muatan nilai budaya luhur manusia.

Kaitannya dengan fenomena tersebut, pembaca kesulitan menemui novel-novel yang mengangkat tentang budaya luhur bangsa yang sebenarnya kaya pengajaran tentang nilai-nilai budaya. Sastrawan yang mengangkat nilai budaya sebagai sebuah cerita dapat dihitung dengan jari atau hanya segelintir saja, misalnya untuk penulis muda yang cukup kompetitif dan berkulitas dalam menuliskan novel adalah Faisal Oddang. Beliau hanya segelintir sastrawan muda yang mau dam mampu menuliskan cerita dengan berlatar salah satu budaya Indonesia, yaitu budaya yang ada di Toraja.

Fenomena tersebut membuat guru cukup kesulitan memilih materi pembelajaran sastra, khususnya novel dengan muatan cerita yang baik. Novelnovel yang beredar sekarang memang lebih banyak jumlahnya dan beragam namun nilai yang terkandung di dalamnya diragukan. Karya sastra yang baik, dalam hal ini adalah novel tidak hanya boleh untuk dinikmati saja namun juga harus memberikan pengajaran bagi pembacanya melaui nilai-nilai yang terkandung di dalamnya. Banyak pendidik yang setuju bahwa pembelajaran sastra adalah salah satu cara membuat orang menjadi manusia dan masyarakat yang lebih baik (Showalter, 2007: 22). Jangan sampai setelah membaca karya sastra bukan pengajaran baik yang didapat oleh pembaca namun hal negatif didapatkan.

Novel Gadis Pantai merupakan salah satu novel yang menyuguhkan dan mengangkat nilai-nilai dalam masyarakat beserta budaya yang melekat di dalamnya. Novel Gadis Pantai mengandung nilai sosial yaitu nilai kejujuran, nilai ketekunan, nilai tolong menolong, nilai kesopanan, dan nilai individu. Nilai-nilai tersebut sangat berkaitan dengan latar belakang cerita tersebut. Melalui novel Gadis Pantai, Pramoedya Ananta Toer ingin meperjuangkan keselarasan kelas sosial saat itu (Astuti, 2016: 7). Oleh karena itulah novel Gadis Pantai karya

BASASTRA Jurnal Bahasa, Sastra, dan Pengajarannya

Volume 8 Nomor 1, April 2020, P-ISSN 2302-6405, E-ISSN 2714-9765 
Pramoedya Ananta Toer dapat dijadikan sebagai salah satu referensi materi pembelajaran sastra bagi peserta didik SMA.

\section{METODE PENELITIAN}

Penelitian ini adalah penelitian karya sastra dengan menggunakan analisis dokumen berupa studi pustaka yang bersifat kualitatif. Penelitian kualitatif menitikberatkan pada pemahaman tentang fenomena apa yang dialami oleh subjek penelitian, misalnya perilaku, persepsi, motivasi, tindakan, dan lain-lain secara holistik dan dengan cara deskripsi dalam bentuk kata-kata dan bahasa, pada suatu konteks khusus yang alamiah dan dengan memanfaatkan metode alamiah (Moleong, 2014: 6).

Data dalam penelitian ini adalah hasil telaah dokumen novel Gadis Pantai karya Pramoedya Ananta Toer sesuai dengan rumusan masalah yang disampaikan. Sumber data dalam penelitian ini adalah dokumen dan informan. Adapun yang menjadi informan dalam penelitian ini adalah guru bahasa Indonesia dan sastra SMA, pembaca novel Gadis Pantai, serta sastrawan atau ahli sastra.

Teknik pengambilan sampel dalam penelitian ini adalah purposive sampling. Purposive sampling dilakukan dengan mengambil orang-orang yang terpilih betul oleh peneliti berdasaran ciri-ciri spesifik yang dimiliki oleh sampel itu (Nasution, 2012: 98). Teknik pengumpulan data dalam penelitian ini adalah analisis dokumen dan wawancara. Analisis dokumen adalah suatu teknik pengumpulan data dengan menghimpun dan menganalisis dokumen-dokumen, baik dokumen tertulis, gambar maupun elektronik (Sukmadinata, 2013: 221).

Validitas data yang digunakan dalam penelitian ini adalah teknik triangulasi. Triangulasi menghindarkan terjadinya kesalahan interpretasi dengan cara memanfaatkan persepsi yang beragam, mengidentifikasi cara pandang yang berbeda-beda (Ratna, 2010: 243). Dalam penelitian ini digunakan triangulasi teori dan sumber data.

Teknik analisis data yang digunakan dalampenelitian ini adalah teknik analisis interaktif (interactive model of analysis). Komponen-komponen analisis data meliputi: (1) periode pengumpulan data, (2) reduksi data, (3) penyajian data, dan (4) penarikan kesimpulan (Miles, Hubermen, \& Saldana, 2014).

\section{HASIL DAN PEMBAHASAN \\ Latar Belakang Pengarang}

Latar belakang pengarang mempengaruhi proses penciptaan karya khususnya latar sosial dan budaya yang tercermin dalam sebuah karya sastra. Novel Gadis Pnatai karya Pramoedya Ananta Toer adalah salah satu novel yang mencerminkan identitas kebudayaan yang melekat pada pengarang dilihat dari jalan cerita, nilai-nilai yang tercermin, dan latar sosial budaya yang terkandung dalam cerita dalam novel. Pramoedya Ananta Toer adalah salah satu pengarang yang menciptakan karyanya dengan tujuantujuan tertentu yang ingin disampiakan kepada pembaca.

Pada novel Gadis Pantai, Pramoedya ingin mengkritisi adanya sistem feodalisme jawa yang begitu kokoh dipertahankan oleh kalangan-kalangan tertentu. Sistem feodalisme jawa dianggap menciptakan penindasan terhadap kalangan kelas bawah. Selain itu Pramoedya ingin menyampaikan protes terhadap tatanan feodal jawa yang menganggap bahwa golongan atas selalu mempertahankan identitas dan kedudukannya sebagai seorang bangsawan atau dalam istilah jawa disebut priyayi dengan cara-cara tertentu, misalkan dalam novel Gadis Pantai sosok tokoh Gadis Pantai tidak dapat resmi menjadi istri seorang bangsawan Jawa hanya karena

BASASTRA Jurnal Bahasa, Sastra, dan Pengajarannya

Volume 8 Nomor 1, April 2020, P-ISSN 2302-6405, E-ISSN 2714-9765 
tidak berasal dari golongan kelas yang sama.

Novel Gadis Pantai sebagai salah satu karya Pramoedya Ananta Toer menampilkan cermin gaya kepenulisan pengarang dalam menyajikan cerita. Pramoedya menolak adanya gagasan seni untuk seni (art for art's sake) karena dirinya ingin menampilkan bahwa karya haruslah mempunyai tujuan tertentu agar dapat memberikan edukasi kepada pembaca, sehingga dapat disimpulkan bahwa Pramoedya tergolong dalam sastrawan yang menganut seni untuk kehidupan (art for life's sake) . Hal ini tentu saja tidak dapat terlepas dari latar belakang sosial budaya Pramoedya yang tumbuh di tengah-tengah keluarga aktivis politik terutama ayah Pramoedya yang merupakan kader partai politik. Terlepas dari latar belakang keluarga Pramoedya, latar belakang sosialnya yang aktif dalam Lekra (Lembaga Kebudayaan Rakyat) turut mempengaruhi karya-karya yang tercipta.

\section{Bentuk Pengungkapan Unsur-Unsur Budaya Jawa dalam Novel Gadis Pantai Karya Pramoedya Ananta Toer}

Pengungkapan unsur-unsur budaya Jawa dalam novel Gadis Pantai karya Pramoedya Ananta Toer dilakukan dalam berbagai bentuk dengan ditandai dengan keunikan dan identitas yang ada dalam unsur kebudayaan Jawa. Beragam unsurunsur budaya Jawa yang tercermin dalam novel Gadis Pantai karya Pramudya Ananta Toer diidentifikasikan dan dianalisis guna mendapatkan bentuk pengungkapan unsur-unsur budaya Jawa yang benar-benar tercermin dalam novel. Beberapa bentuk pengungkapan unsurunsur budaya Jawa yang ada dalam novel Gadis Pantai karya Pramoedya Ananta Toer, yaitu.

Penggunaan Bahasa Masyarakat Jawa Disesuaikan dengan Kedudukan, Umur, Status, dan Tingkat Keakraban.
Berikut kutipan dalam novel yang menggambarkan unsur bahasa dalam masyarakat Jawa.

"Bujang itu tertawa terkekeh ditekan. Dipandanginya majikannya yang baru terlampau muda itu, dibelainya dagunya yang licin seperti kepala lele. Dan akhirnya dengan empu jari ia menuding ke dada orang yang dilawannya bicara."(Toer, 2018: 27)

Kutipan tersebut menjelaskan bahwa seorang yang derajat dan pangkatnya lebih rendah berusaha menjaga tata krama dalam komunikasi dengan menggunakan bahasa tubuh. Bahasa tubuh tersebut tampak pada adegan menudingkan ibu jari kepada lawan tutur yang mempunyai derajat lebih tinggi darinya. Alasan penggunaan ibu jari sebagai alat untuk menuding lawan tutur mengindikasikan bahwa hal tersebut menunjang tata krama dan kesopanan terhadap lawan tutur yang lebih tinggi derajatnya.

\section{Sistem Pengetahuan Masyarakat Jawa yang Beralkulturasi dengan Sistem Pengetahuan Kolonial Belanda.}

Berikut adalah penggalan novel yang menggambarkan sistem pengetahuan yang berlaku pada masyarakat Jawa.

"Betapa hebat Bendoro mengajar putera-puteranya," kepala kampong berbisik. "Sekecil itu sudah bisa bicara bahasa Belanda. Satu kata pun kita tak paham. Anakmu nanti," kepala kampung menghadapkan mukanya kepada Gadis Pantai, "juga bakal seperti itu." Gadis Pantai kecut, wajahnya meraih tangan emak dan menggenggamnya erat-erat. (Toer, 2018: 21)

Kutipan tersebut menggambarkan bahwa pada masa pendudukan kolonial Belanda, sistem pengetahuan masyarakat Jawa terpengaruh oleh sistem pengetahuan

BASASTRA Jurnal Bahasa, Sastra, dan Pengajarannya

Volume 8 Nomor 1, April 2020, P-ISSN 2302-6405, E-ISSN 2714-9765 
kolonial Belanda. Pada kutipan di atas digambarkan bahwa seorang anak Bendoro dapat bicara dengan bahasa Belnada yang lazimnya tidak dapat dikuasai oleh masyarakat Jawa ada umumnya. Bahasa Belanda hanya dapat dikuasai dan diajarkan kepada golongan kelas atas yang sering bersinggungan langsung dengan pemerintah kolonial Belanda. Hal tersebut dibuktikan dengan penyataan Kepala Kampung yang terheran-heran dengan putra Bendoro yang dapat mengusai bahasa Belanda di usia belia.

\section{Sistem Kemasyarakatan Masyarakat Jawa Menganut Sistem Feodalisme yang Kuat.}

Berikut penggalan yang menggambarkan adanya kelas-kelas sosial pada masyarakat Jawa.

"Dia pembesar, nak, orang berkuasa, sering dipanggil Bendoro Bupati. Tuan Besar residen juga pernah datang ke rumahnya, nak. Semua orang tahu." (Toer, 2018: 14)

Kutipan tersebut menggambarkan bahwa bangsawan dipandang oleh masyarakat sebagai golongan yang dihormati dan disegani. Bangsawan pada zaman sebelum kemerdekaan Indonesia memiliki kekuasaan yang menyebabkan masyarakat di sekelilingnya secara de facto tunduk dan patuh terhadap perintahnya. Selain itu bangsawan pada era kolonialisme Belanda sering bersinggungan dengan pemerintah kolonial Belanda dan pembesar pemerintahan pada saat itu seperti residen dan bupati.

Sistem Teknologi dan Peralatan yang Bekembang pada Kehidupan Masyarakat Jawa Mengalami Perkembangan.

Keberagaman sistem teknologi yang berkembang pada masyarakat Jawa dapat dilihat dari beberapa kriteria. Pertama, sistem teknologi yang berkembang dapat diamati dan tergambar dari bentuk serta keanekaragaman jenis, corak, atau warna yang menjadi identitas masyarakat Jawa. Kedua, dapat dipandang dari gaya arsitektur bangunan yang berkembang dalam lingkungan masyarakat Jawa. Ketiga, perkembangan teknologi kesehatan pada masyarakat Jawa dapat diamati sebagai tolak ukur sejauh mana ilmu kesehatan dapat berkembang di lingkungan kebudayaan masyarakat Jawa. Keempat, berbagai jenis sajian menu makanan yang disajikan dan dikonsumsi masyarakat Jawa dapat menggambarkan ilmu pengolahan makanan yang berkembang dalam masyarakat Jawa.

Kutipan di bawah ini dapat mencerminkan salah satu wujud pengungkapan budaya Jawa yang terlihat dari perkembangan gaya berpakaian masyarakat Jawa pada era kolonialisme Belanda. Masyarakat pada era kolianlisme Belnada khususnya golongan priyayi atau bangsawan sering menggunakan atribut pakaian yang berkolaborasi dengan kebudayaan Barat seperti berikut ini.

"Ia dengar bunyi buut terkenal itu. Jantungnya berdebar. Ia tutup pintunya rapat-rapat, tetapi ia tiada menguncinya. Tidak! Bendoro tidak membawa wanita utama baru, ia menjerit dalam hati."'(Toer, 2018: 88)

Kutipan tersebut menggambarkan gaya berpakaian masyarakat Jawa khusunya kaum bangsawan yang tidak selalu identik dengan pakaian adat Jawa pada umumnya. Percampuran kebudayaan yang disebabkan adanya interaksi antara kebudayaan Jawa dan kebudayaan Barat menjadikan gaya berpakaian bangsawan Jawa bercampur dengan gaya berpakaian Barat. Dalam kutipan digambarkan terdengar bunyi buut dipakai oleh tokoh Bendoro yang artinya tokoh Bendoro menggunakan alas kaki buut yang lazimnya digunakan masyarakat Barat pada era kolonial Belanda. Namun terkadang tokoh Bendoro tetap

BASASTRA Jurnal Bahasa, Sastra, dan Pengajarannya

Volume 8 Nomor 1, April 2020, P-ISSN 2302-6405, E-ISSN 2714-9765 
menggunakan alas kaki yang lazim memang digunakan oleh bangsawan Jawa pada masa itu yaitu selop, seperti pada kutipan di bawah ini.

"Terdengar bunyi selop berhenti, kemudian "Mengapa aku tak dibangunkan? Suruh ke sini kepala kampung itu!" (Toer, 2018: 22)

Kutipan tersebut menceritakan atribut pakaian dari tokoh Bendoro yang menggunakan alas kaki berupa selop. Alas kaki selop memang umum dipakai oleh masyarakat Jawa. Jadi dilihat dari atribut pakaian yang dikenakan oleh tokoh Bendoro dapat disimpulkan bahwa terkadang ada percampuran gaya berpakaian golongan priyayi utamanya yang sering berinteraksi dengan kaum kolonial Belanda. Perpaduan gaya berpakaian menggabungkan antara gaya berpkaian masyarakat Jawa dengan gaya berpakaian masyarakat Barat.

Mata Pencaharian Masyarakat Jawa Dipengaruhi Oleh Kondisi Geografis dan Alam Sekitarnya.

Berikut menggambarkan kutipan yang masyarakat Jawa.

"Hari demi hari batinnya diisi derai ombak dan pandangnya oleh perahu-perahu yang berangkat di subuh hari pulang di siang hari atau sore hari, berlabuh di muara, menurunkan ikan tangkapan dan menunggu besok sampai kantor lelang buka."(Toer, 2018: 1)

Kutipan tersebut menggambarkan kehidupan kaum yang tinggal di pesisir pantai dengan mata pencaharian sebagai nelayan yang sehari-hari berlayar ke laut. Hasil tangkapan ikan dari pelayaran mejadi mata pencaharian utama masyarakat pesisir. Hasil tangkapan kemudian di lelang demi mendapatkan uang. Kehidupan tersebut merupakan gambaran masyarakat Jawa yang menggantungkan mata pencahariaannya dari alam sekitar, seperti contohnya adalah laut.

Mata pencaharian lain yang menjadi sumber pendapatan masyarakat Jawa saat itu adalah melalui perdagangan. Masyarakat Jawa yang mempunyai pekerjaan sebagai pedagang biasa bertempat tinggal di kota. Hal ini dipengaruhi oleh faktor pendukung perekonomian masyarakatnya yang bergantung pada aktivitas perdagangan. Berikut kutipan yang menggambarkan mata pencaharian masyarakat Jawa sebagai pedagang.

"Semua itu pernah dilihatnya dua tahun yang lalu, waktu dengan orang-orang sekampung datang ke kota, nonton pasar malam. Ia masih ingat buaya yang dipajang di atas pintu toko sepatu. Ia masih ingat toko pabrik tegel dengan bunga-bunganya yang berwarnawarni." (Toer, 2018: 15)

Kutipan tersebut menggambarkan kondisi mata pencaharian masyarakat Jawa yang tinggal di kota. Berdagang menjadi kegiatan ekonomi yang menunjang penghasilan. Kondisi demikian dikarenakan lingkungan tempat tinggal masyarakat Jawa perkotaan yang tidak memungkinkan memanfaatkan alam sekitar sebagai mata pencaharian. Hal ini lah yang membedakan antara masyarakat Jawa di pedesaan dan masyarakat Jawa perkotaan.

Sistem Kepercayaan dan Agama Masyarakat Jawa Dipengaruhi Oleh Budaya Animisme dan Dinamisme.

Sistem kepercayaan dan agama yang dianut masyarakat Jawa pada masa kolonial masih dipengaruhi oleh kebudayaan animisme dan dinamisme. Masyarakat Jawa saat itu sebagian sudah memeluk agama tertentu, seperti agama Islam yang mayoritas dianut oleh kalangan priyayi santri saat itu. Adapun sebagian masyarakat Jawa saat itu masih memercayai hal-hal yang bersifat

BASASTRA Jurnal Bahasa, Sastra, dan Pengajarannya

Volume 8 Nomor 1, April 2020, P-ISSN 2302-6405, E-ISSN 2714-9765 
animisme dan dinamisme yang terbawa dari kebudayaan jawa kuno serta sebaggian lagi bahkan tidak memeluk kepercayaan atau agama apapun. Berikut penggambaran mengenai sistem kepercayaan dan agama masyarakat Jawa.

"Matanya tak juga terpejam. Dan ia sudah lupa, apakah ia senang atau tidak. Malam kian larut. Dari ruang tengah mulai terdengar sekecang tenaga orang mengaji. Suaranya dalam, merongga, seperti guruh keluar dari gua di bawah gunung. Tak pernah ia dengar orang mengaji seindah itu." (Toer, 2018: 31)

Kutipan tersebut menggambarkan aktivitas atau kegiatan keagamaam seorang yang menganut agama Islam. Kegiatan yang digambarkan pada kutipan novel adalah kegiatan mengaji. Kegiatan mengaji adalah kegiatan membaca kitab suci Al Quran yang dilakukan oleh seorang beragama Islam. Orang mengaji yang digambarkan dalam kutipan mempunyai suara yang merdu sehingga menandakan kefasihan seseorang dalam membaca $\mathrm{Al}$ Quran sebagai kitab suci agama Islam.

Sistem kepercayaan lain yang berkembang pada masyarakat Jawa saat itu adalah kepercayaan animisme dan dinamisme. Kedua sistem kepercayaan tersebut selalu menganggap segala sesuatu mempunyai kekuatan seperti benda-benda yang kemungkinan besar ada di sekitar. Berikut ini penggambaran kepercayaan animisme dan dinamisme pada masyarakat Jawa.

"Kakek itu pernah bilang mBok, segalanya bersumber di laut. Tak ada yang lebih berkuasa dari laut. Nenek moyang kami juga bakal tidak ada kalau laut tidak ada." (Toer, 2018: 86)

Kutipan tersebut menggambarkan sistem kepercayaan masyarakat Jawa saat itu yang memercayai adanya kekuatan besar dari alam maupun nenek moyang.
Tokoh Kakek yang diceritakan dalam kutipan di atas menganggap laut adalah sumber kekuatan tersebsar dan tidak ada yang lebih berkuasa selain laut. Hal ini menggambarkan kepercayaan animisme dan dinamisme masyarakat Jawa saat itu masih dianut dan dipercayai sebagian orang.

\section{Keragaman Kesenian yang Berkembang pada Masyarakat Jawa \\ Berikut kutipan yang} menggambarkan perkembangan kesenian masyarakat Jawa dalam novel Gadis Pantai.

"Antara ruang tengah dan pendopo menganga sebuah pintu raksasa yang separuhnya tertutup penyekat lipat yang terbuat dari kayu sonokeling dengan ukiran Jepara dan ditutupi dengan anyaman kulit bambu halus bersulamkan benang emas yang menggambarkan laut."'(Toer, 2018: 79)

Kutipan di atas menggambarkan kesenian ukir yang menjadi aksesoris penghias rumah. Seni ukir yang tergambar dalam kutipan novel mencerminkan identitas seni ukir yang menjadi jati diri daerah Jepara saat itu. Seni ukir bahkan menjadi lambang identitas kebudayaan Jawa khususnya di daerah Jepara yang menjadi sentra perkembangan seni ukir.

\section{Nilai Sosial dalam Novel Gadis Pantai karya Pramoedya Ananta Toer \\ Novel Gadis Pantai yang} merupakan karya Pramoedya Ananta Toer dapat diidentifikasi nilai sosial apa saja yang ada di dalamnya. Berikut identifikasi dan deskripsi mengenai nilai-nilai sosial yang terkandung dalam Gadis Pantai karya Pramoedya Ananta Toer. Berikut ini adalah nilai-nilai sosial yang terkandung dalam novel Gadis Pantai karya Pramoedya Ananta Toer.

\section{Nilai Kejujuran}

Berikut kutipan dalam novel Gadis Pantai yang menunjukkan nilai kejujuran.

BASASTRA Jurnal Bahasa, Sastra, dan Pengajarannya

Volume 8 Nomor 1, April 2020, P-ISSN 2302-6405, E-ISSN 2714-9765 
“ 'Tidak pernah kau kirim utusan ke sana?'

'Tidak Bendoro.'

'Tentu aku percaya. Tak pernah kirim uang atau pakaian ke sana?'

'Tidak Bendoro.'

'Aku percaya, tapi mengapa?'

'Sahaya tak berani Bendoro.

Sahaya hanyalah sahaya.' " (Toer, 2018: 108)

Kutipan tersebut menggambarkan kejujuran tokoh Gadis Pantai saat ditanya oleh tokoh Bendoro. Tokoh Gadis Pantai tidak berani berbohong karena ketaatannya pada tokoh Bendoro. Gadis Pantai tidak berani mengirimkan barang ke kampung halamannya tanpa seizin Bendoro karena merasa hal tersebut menyalahi aturan.

\section{Nilai Ketekunan}

Berikut kutipan dalam novel Gadis Pantai karya Pramoedya Ananta Toer yang mencerminkan nilai ketekunan tokohnya.

"Dan ia pun kenangkan kampung nelayan nun jauh di tepi pantai, hari-hari yang penuh tawa, keringat yang mengucur rela, tangan-tangan yang coklat kuat, dan lemah lembut dan kasar yang pada saling membantu." (Toer, 2018: 133)

Kutipan tersebut menggambarkan kondisi kampung nelayan yang warganya rata-rata harus berkerja keras. Masyarakat di sana digambarkan sebagai masyarakat yang pekerja keras dan tidak kenal lelah. Kerja keras yang ditunjukan oleh masyarakat kampung nelayan tersebut merupakan indikator nilai ketekunan. Hal tersebut dibuktikan dengan kondisi tangan yang kasar dan kulit yang berwarna coklat karena tersengat sinar matahari. Kondisi demikian menandakan masyarakat di kampung nelayan berkerja setiap waktu dengan tantangan medan yang keras dan sulit sehingga mempengaruhi kondisi fisiknya.

Nilai Tolong Menolong
Berikut penggalan novel yang mencerminkan nilai tolong menolong.

" 'Aku sakit, mBok. Bawa aku ke kamar mandi,'diulurkannya kedua belah tangannya minta dibangunkan.

Wanita itu meraihkan lengannya, di bawah tengkuk Gadis Pantai, mendudukkannya, merapikan rambutnya yang kacau-balau, membenahi baju dan kainnya yang lepas porak-poranda, menariknarik seprai yang berkerut sanasini' " (Toer, 2018: 72)

Kutipan tersebut menggambarkan tokoh Gadis Pantai yang meminta bantuan kepada tokoh Mbok untuk dibawa ke kamar mandi. Tokoh Mbok dengan sigap menolong dengan memapah dan membantu bangun Gadis Pantai yang terbaring kesakita di ranjang. Selain itu, tokoh Mbok juga membantu merapikan tempat tidur Gadis Pantai yang berantakan.

\section{Nilai Kesopanan}

Berikut kutipan dalam novel Gadis Pantai yang menampilkan ketataatan masyarakat terhadap sistem nilai kesopanan.

"Gadis Pantai dan pelayan tua itu kini terhenti memunggungi pintu, menghadapi pemuda-pemuda itu. Gadis Pantai tetap menunduk ketakutan, sedang pelayan tua itu meradang menantang. Dengan suara perlahan, sopan, dan hati-hati pelayan tua mengacarai, 'Apa yang masih dirundingkan?' "(Toer, 2018: 113)

Kutipan tersebut menggambarkan perilaku tokoh Mbok atau pelayan tua yang tetap sopan terhadap orang lain walaupun dalam keadaan marah. Tokoh Mbok tetap memperlihatkan kesopanannya terhadap pemuda-pemuda yang telah membuatnya marah. Tokoh Mbok berbicara dengan sopan dan hati-hati karena menghormati adab nilai kesopanan sebagai individu Jawa yang selalu andhap asor.

BASASTRA Jurnal Bahasa, Sastra, dan Pengajarannya

Volume 8 Nomor 1, April 2020, P-ISSN 2302-6405, E-ISSN 2714-9765 


\section{Nilai Individu}

Berikut kutipan dalam novel yang menggambarkan adanya nilai individu dalam novel Gadis Pantai.

Aku cuma bawa bayiku sendiri. Bayiku! Bayi yang kulahirkan sendiri. Dia anakku, bapaknya seorang setan, iblis. Lepaskan! (Toer, 2018: 264)

Kutipan tersebut menggambarkan usaha tokoh Gadis Pantai dalam mempertahankan anaknya. Gadis Pantai sebagai seorang ibu yang sudah mengandung dan melahirkan anak kandungnya merasa berhak untuk mengasuh, namun ternyata Gadis Pantai tidak diperbolehkan untuk membawa dan mengasuh anaknya. Gadis Pantai akhirnya melakukan perlawanan untuk mendapatkan hak asuh anak namun berhasil digagalkan. Usaha Gadis Pantai ini merupakan upaya pemertahanan hak seorang individu yang digambarkan dengan usaha dalam mendapatkan dan mempertahankan hak asuh anak kandungnya.

\section{Relevansi Unsur-Unsur Budaya Jawa dan Nilai Sosial Novel Gadis Pantai dengan Materi Pembelajaran Sastra di SMA}

Novel sebagai materi pembelajaran sastra harus memenuhi beberapa kriteria. Kriteria tersebut didasarkan atas Permendikbud nomor 8 tahun 2016 tentang buku yang digunakan oleh Satuan Pendidikan, dalam peraturan tersebut novel diklasifikasikan dalam jenis buku non teks. Novel sebagai buku non teks yang digunakan sebagai materi pembelajaran dalam satuan pendidikan wajib memenuhi kelayakan dari segi aspek materi, aspek kebahasaan, aspek penyajian materi, dan kelayakan kegrafikaan yang tercantum dalam pasal 3 ayat 6 .

Novel Gadis Pantai karya Pramoedya Ananta Toer sebagai salah satu jenis non teks, telah memenuhi unsur kelayakan dari segi aspek materi, aspek kebahasaan, aspek penyajian materi, dan kelayakan kegrafikaan. Pertama, dilihat dari segi aspek materi, novel ini telah memenuhi kelayakan isi yang diantaranya harus mendukung pencapaian pendidikan nasional, tidak bertentangan dengan undang-undang, tidak SARA, memiliki kreativitas yang tinggi, serta materi memuat isi yang dapat membangun karakter bangsa. Kedua, dilihat dari segi aspek kebahasaan, novel ini telah memenuhi kelayakan bahasa yang diantaranya bahasa yang digunakan harus komunikatif, estetis, etis, dan fungsionalis, sesui dengan sasaran pembaca serta bahasa yang disajikan sesuai dengan penulisan kaidah kebahasaan yang baku. Ketiga, dilihat dari segi penyajian materi, novel ini juga telah memenuhi standar penilaian yang berlaku, seperti diantaranya penyajian materi dilakukan dengan memerhatikan unsur-unsur intrinsik serta penyajian materi mengembangkan karakter, kecakapan intelektual, emosional, sosial, spiritual, kewirausahaan, dan ekonomi kreatif. Keempat, dilihat dari segi aspek kegrafikaan, novel telah sesuai dengan indikator penilaian, diantaranya tata letak unsur grafika estetis, dinamis, dan menarik serta tipografi yang digunakan mempunyai tingkat keterbacaan yang tinggi.

Kelayakan dari segi aspek materi, aspek kebahasaan, aspek penyajian materi, dan kelayakan kegrafikaan telah terpenuhi. Namun, selain harus meninjau dari kelayakan keempat aspek, kecocokan denga kompetensi dasar yang ada dalam jenjang SMA juga perlu diperhatikan. Kompetensi dasar yang relevan menggunakan novel Gadis Pantai antara lain KD 3.9 dan KD 4.9 di kelas X wajib, KD 3.17 dan KD 4.17 di kelas XI wajib, KD 3.7 dan KD 4.7 di kelas XI peminatan, KD 3.4, KD 4.4, KD 3.8, KD 4.8, KD 3.9, KD 4.9 di kelas XII wajib, serta KD 3.4 dan KD 4.4 di kelas XII peminatan. Namun secara materi yang benar-benar

BASASTRA Jurnal Bahasa, Sastra, dan Pengajarannya

Volume 8 Nomor 1, April 2020, P-ISSN 2302-6405, E-ISSN 2714-9765 
relevan dan sesuai dengan penggunaan novel Gadis Pantai sebagai materi pembelajaran sastra yaitu KD 3.7 dan 4.7 di kelas XI peminatan serta KD 3.8 dan KD 4.8 di kelas XII wajib. Keseluruhan Kompetensi dasar (KD) tersebut telah sesuai dengan kurikulum 2013 yang termuat dalam Permendikbud Nomor 24 tahun 2016 tentang kompetensi inti dan kompetensi dasar pelajaran pada kurikulum 2013 pada pendidikan dasar dan pendidikan menengah.

\section{SIMPULAN}

Berdasarkan kegiatan pengumpulan data dan analisi data, maka dapat disimpulkan bahwa latar belakang kepengarangan novel Gadis Pantai terispirasi oleh kisah nenek Pramoedya Ananta Toer yang mengalami pernikahan di usia remaja dengan seorang bangsawan Jawa yang tidak dikenal oleh dirinya. Karya-karya Pramoedya juga dipengaruhi oleh kondisi sosial dan keluarga yang ada di sekitarnya. Selain itu, hal lain yang dapat disimpulkan dalam penelitian ini adalah bentuk pengungkapan unsur-unsur budaya Jawa antara lain: (a) penggunaan bahasa masyarakat Jawa disesuaikan dengan kedudukan, umur, status, dan tingkat keakraban; (2) sistem pengetahuan masyarakat jawa yang beralkulturasi dengan sistem pengetahuan kolonial belanda; (3) sistem kemasyarakatan masyarakat jawa menganut sistem feodalisme yang kuat; (4) sistem teknologi dan peralatan yang bekembang pada kehidupan masyarakat jawa mengalami perkembangan; (5) mata pencaharian masyarakat jawa dipengaruhi oleh kondisi geografis dan alam sekitarnya; (6) sistem kepercayaan dan agama masyarakat jawa dipengaruhi oleh budaya animisme dan dinamisme; dan (7) keragaman kesenian yang berkembang pada masyarakat jawa. Selain itu, nilai sosial yang terkandung dalam novel Gadis Pantai antara lain: (1) nilai kejujuran, (2) nilai ketekunan atau kerja keras, (3) nilai tolong menolong, (4) nilai kesopanan, dan (5) nilai individu.

Novel Gadis Pantai karya Pramoedya Ananta Toer karena telah memenuhi kriteria kelayakan dan relevan dengan kompetensi dasar yang diajarkan di SMA. Selain itu, kajian mengenai unsurunsur budaya Jawa dan nilai sosial yang terkandung dalam novel ini dapat menunjang pembelajaran yang berbasis karakter dan nilai-nilai luhur kebangsaa. Oleh karena itu, novel Gadis Pantai karya Pramoedya Ananta Toer layak dan relevan digunakan sebagai materi pembelajaran sastra di SMA, khususnya dalam pebelajaran pada KD 3.7 dan 4.7 di kelas XI peminatan serta KD 3.8 dan KD 4.8 di kelas XII wajib.

\section{REFERENSI}

Astuti, R.D. (2016). Nilai Sosial dalam Novel Gadis Pantai Karya Pramoedya Ananta Toer. Pesona, 2(1), 1-7.

Damono, S.J. 2002. Sosiologi Sebuah Pengantar Ringkas. Jakarta: Pusat Pembinaan dan Pengembangan Bangsa.

Miles, M.B., Huberman, A.M., \& Saldana, J. (2014). Qualitative Data
Analysis (Third Edition). California: Sage Publications.

Minderop, A. (2011). Psikologi Sastra. Jakarta: Yayasan Obor Indonesia.

Moleong, L.J. (2014). Metodologi Penelitian Kualitatif. Bandung: PT Remaja Rosdakarya

Nasution, S. (2012). Metode Research (Penelitian Ilmiah). Jakarta: PT Bumi Aksara.

BASASTRA Jurnal Bahasa, Sastra, dan Pengajarannya

Volume 8 Nomor 1, April 2020, P-ISSN 2302-6405, E-ISSN 2714-9765 
Ratna, N.K. (2010). Metodologi

Penelitian: Kajian Budaya dan Ilmu Sosial Humaniora Pada Umumnya. Yogyakarta: Pustaka Pelajar.

Ronen, R. (1994). Introduction. In Possible Worlds in Literary Theory (Literature, Culture, Theory). Cambridge: Cambridge
University

Press. doi:10.1017/CBO978051159748 0.001

Showalter, E. (2007). Teaching Literature. Malden: Willey-Blackwell.

Sukmadinata, N.S. (2013). Metode Penelitian Pendidikan. Bandung: PT Remaja Rosdakarya. 